\title{
KVK's Impacts on Skill of the Respondents
}

\author{
Anant Kumar ${ }^{1}$ and S. K. Verma ${ }^{2 *}$ \\ ${ }^{1}$ Krishi Vigyan Kendra, Ghaziabad, U.P., India \\ ${ }^{2}$ Krishi Vigyan Kendra, Shahjahanpur -242001, U.P. (Sardar Vallabhbhai Patel University of \\ Agriculture \& Technology, Meerut, U.P.), India \\ *Corresponding author
}

\section{A B S T R A C T}

\section{Keywords}

Krishi Vigyan Kendras, Extension activities

Article Info

Accepted:

20 August 2020

Available Online:

10 September 2020
In the findings it was found that the Krishi Vigyan Kendras are functional carrying out extension activities in accordance with government programme schedule and proving support to raise the skill of the farmers which will help them to increase their productivity. Highest adoption at KVKs was found by the KVK of Shahjahanpur, may be due to better and adequate infrastructure and other facilities. Nearly 50 percent beneficiaries admitted that after receiving training from $\mathrm{KVK}$, their productivity also increased. 50 percent beneficiaries have fully adopted recommendations of the KVK while 36 percent adopted it partially.

\section{Introduction}

Induction of the appropriate technology holds key to the rapid development and transformation of the rural society in a sustainable manner. The transfer of technology among the rural masses is the challenging task facing the country. Training of farmers and in-service extension functionaries are a critical input for the rapid transfer of agricultural technology. This aspect remained neglected in the past and continues as a weak link in the agricultural production system even now. The training institutions which existed were by and large theoretically oriented and hence they could not make as much dent on production and generating income in the farming community as was expected. Realizing this crucial gap, the Indian Council of Agricultural Research (ICAR) evolved Krishi Vigyan Kendra (KVK) as an innovative institution for vocational training in agriculture and allied subjects.

The experience gathered so far reveals that in spite of various approaches and programmes adopted, the technologies have not yet been transferred to the majority of the users. It may be due to several reasons. One of the reasons is the lack of basic understanding of the principles involved in the transfer of 
technology (TOT) on the part of scientists, extension workers and the change agents, as well as the lack of integrated approach by scientists and extension workers and users of technology. So, to evaluate the effectiveness and performance of selected three Krishi Vigyan Kendras on the farmers of the area, the present study entitled "KVKs impact on skill of the respondents.

\section{Materials and Methods}

\section{Selection of the Krishi Vigyan Kendras}

The present study was conducted in three Krishi Vigyan Kendra i.e. Krishi Vigyan Kendra, Shahjahanpur, Krishi Vigyan Kendra, Hardoi and Krishi Vigyan Kendra, Bareilly

\section{Selection of villages}

Five villages were selected from the each selected KVK for the selection of the respondents, two adjacent to $\mathrm{KVK}$, two in the radius of 15-20 kilometers and one beyond 20 kilometers from the KVK. Only such villages selected where farmers attended the training programmes of the KVK. 20 respondents were selected from each selected village.

\section{Selection of respondents}

The lists of beneficiaries of three selected Krishi Vigyan Kendra were prepared. 100 beneficiaries from each selected Krishi Vigyan Kendra were selected randomly as respondents for the study. By this the total 300 beneficiaries were selected from three Krishi Vigyan Kendras.

\section{Socio-economic status}

Scoring techniques of socio-economic status suggested by Trivedi, G. and Pareek, U. (1964) with slight modification was followed.

\section{Communication behavior}

To study the communication behavior and information sources utilization pattern (ISUP), the availability, contact and competency for understanding was included. After pre-testing the schedule with a group of farmers so far as the contact of the respondent with each information source is concerned, each source was measured on 3 point continuous (Frequently, Occasionally, Rarely) and 3,2 and 1 score value was assigned to each level on positive question while in negative question score were assigned as reverse 1, 2 and 3.Information sources utilization pattern of the respondents was categorized into three categories by the formula:

Maximum value - minimum value $={ }^{\prime} x$ '

\section{3}

Average value $=\mathrm{x} ; 0-\mathrm{x}=$ class interval; as low, medium and high respectively.

\section{Collection and analysis of the data}

The data was collected from the selected respondents with the help of pre-tested interview schedule by the researcher herself. The data from the sample farmers were collected personally with the help of interview schedule by survey method. After that, the data so collected was arranged, classified qualified and tabulated systematically.

\section{Results and Discussion}

Socio-economic characteristics of
respondents

\section{Monthly income}

It is obvious that the person with higher monthly income takes more interest in 
improving their level of living. The following table shows the regular monthly income of the beneficiaries of the Krishi Vigyan Kendra.

From the above table 1 it is evident that 35.67 percent beneficiaries were in monthly income group of Rs.5000 to 10000 followed by the group of up to Rs. 5000 with 34.33 percent. 30 percent beneficiaries were in monthly income group of Rs.10001 and above. Thus, it can be concluded that majority of beneficiaries were from Rs. 5000 to 10000 monthly income group Arene (1994) was also given similar findings.

\section{Literacy}

It is well known that the people with formal education are more aware of their life and new innovations. The following table shows the educational level of the beneficiaries of the Krishi Vigyan Kendra.

The table 2 shows that still the majority of beneficiaries are not able to attain high level of education. As such 35 percent of the beneficiaries were having education up to primary school or were illiterate. Beneficiaries having education up to junior high school and high school were 18.33 and 12.66 percent, respectively. 10.33 percent beneficiaries were having the education up to intermediate level. However, only 8.33 percent beneficiaries were graduates.

It can be derived from the above data that maximum number of beneficiaries belongs to poor educational background (Illiterate and Primary school).Similar findings were also given byBorude et al., (1987).

\section{Size of family}

The following table shows the number of the family members of beneficiaries of the Krishi Vigyan Kendra.
The table 3 indicates that 48.34 percent beneficiaries were having family of up to 6 members where as 51.66 percent beneficiaries were having family members above 6 members. Thus, it can be concluded that majority of beneficiaries were having joint family system. The results obtained are in conformity with those of Anon (1995).

\section{Occupation}

It is general opinion that farmers, whose main occupation is farming, take more of their land in a systematic manner and adopt new technologies of Agriculture than the others. The following table shows the main occupation of the respondents.

It is apparent from the table 4 that 78.34 percent beneficiaries were having farming as their main occupation while 11 percent beneficiaries were having farming and business as their occupation. 10.66 percent beneficiaries were having farming and service as their occupation. Thus, it can be concluded that majority of beneficiaries were having farming as their main occupation Anon (1995).

\section{Land holding}

It is also a general opinion that large farmers are more innovative than the small and marginal farmers. The following graph 1 shows the land holdings of the respondents. From the graph 1 it is evident that 51.66 percent beneficiaries were small farmers where as 27.34 percent beneficiaries were marginal farmers. 13.67 percent beneficiaries were semi-large farmers while only 7.33 percent beneficiaries were large farmers.

Thus, it can be concluded that majority of beneficiaries were having small and marginal land holdings. 
Table.1 Distribution of beneficiaries according to their monthly income

\begin{tabular}{|c|c|c|c|c|c|}
\hline $\begin{array}{c}\text { S. } \\
\text { No. }\end{array}$ & $\begin{array}{c}\text { Monthly income } \\
\text { (Rs.) }\end{array}$ & \multicolumn{4}{|c|}{ Number of Beneficiaries } \\
\cline { 3 - 6 } & KVK Hardoi & $\begin{array}{c}\text { KVK } \\
\text { Shahjahanpur }\end{array}$ & $\begin{array}{c}\text { KVK } \\
\text { Bareilly }\end{array}$ & Total \\
\hline 1. & Up to 5000 & $40(40.00)$ & $29(29.00)$ & $34(34.00)$ & $103(34.33)$ \\
\hline 2. & $5000-10000$ & $28(28.00)$ & $44(44.00)$ & $35(35.00)$ & $107(35.67)$ \\
\hline 3. & 10001 and above & $32(32.00)$ & $26(26.00)$ & $31(31.00)$ & $90(30.00)$ \\
\hline & Total & $\mathbf{1 0 0}$ & $\mathbf{1 0 0}$ & $\mathbf{1 0 0}$ & $\mathbf{3 0 0}$ \\
\hline
\end{tabular}

Table.2 Distribution of beneficiaries according to their education

\begin{tabular}{|c|c|c|c|c|c|}
\hline S.N. & $\begin{array}{c}\text { Educational level } \\
\text { of the respondents }\end{array}$ & KVK Hardoi & $\begin{array}{c}\text { Number of Beneficiaries } \\
\text { KVK }\end{array}$ & $\begin{array}{c}\text { KVK } \\
\text { Bareilly }\end{array}$ & Total \\
\hline $\mathbf{1 .}$ & Illiterate & $20(20.00)$ & $12(12.00)$ & $11(11.00)$ & $43(14.33)$ \\
\hline $\mathbf{2 .}$ & Can read only & $19(19.00)$ & $9(9.00)$ & $13(13.00)$ & $41(13.67)$ \\
\hline $\mathbf{3 .}$ & Primary School & $28(28.00)$ & $24(24.00)$ & $15(15.00)$ & $67(22.33)$ \\
\hline $\mathbf{4 .}$ & J.H.S & $12(12.00)$ & $18(18.00)$ & $25(25.00)$ & $55(18.33)$ \\
\hline $\mathbf{5 .}$ & High School & $9(9.00)$ & $17(17.00)$ & $12(12.00)$ & $38(12.66)$ \\
\hline $\mathbf{6 .}$ & Intermediate & $7(2.00)$ & $10(10.00)$ & $14(14.00)$ & $31(10.33)$ \\
\hline $\mathbf{7}$ & Graduate & $5(5.00)$ & $10(10.00)$ & $10(10.00)$ & $25(8.33)$ \\
\hline & Total & $\mathbf{1 0 0}$ & $\mathbf{1 0 0}$ & $\mathbf{1 0 0}$ & $\mathbf{3 0 0}$ \\
\hline
\end{tabular}

Table.3 Distribution of beneficiaries according to their Size of family members

\begin{tabular}{|c|c|c|c|c|c|}
\hline \multirow{2}{*}{ S. } & Size of family & \multicolumn{4}{|c|}{ Number of Beneficiaries } \\
\cline { 3 - 6 } No. & & $\begin{array}{c}\text { KVK } \\
\text { Hardoi }\end{array}$ & $\begin{array}{c}\text { KVK } \\
\text { Shahjahanpur }\end{array}$ & $\begin{array}{c}\text { KVK } \\
\text { Bareilly }\end{array}$ & Total \\
\hline 1. & Up to 6 member & $48(48.00)$ & $56(56.00)$ & $41(41.00)$ & $145(48.34)$ \\
\hline 2. & Above 6 member & $52(52.00)$ & $44(44.00)$ & $59(59.00)$ & $155(51.66)$ \\
\hline & Total & $\mathbf{1 0 0}$ & $\mathbf{1 0 0}$ & $\mathbf{1 0 0}$ & $\mathbf{3 0 0}$ \\
\hline
\end{tabular}

Table.4 Distribution of beneficiaries according to their main occupation

\begin{tabular}{|c|c|c|c|c|c|}
\hline \multirow{2}{*}{$\begin{array}{c}\text { S. } \\
\text { No. }\end{array}$} & Occupation & \multicolumn{4}{|c|}{ Number of Beneficiaries } \\
\cline { 3 - 6 } & & $\begin{array}{c}\text { KVK } \\
\text { Hardoi }\end{array}$ & $\begin{array}{c}\text { KVK } \\
\text { Shahjahanpur }\end{array}$ & $\begin{array}{c}\text { KVK } \\
\text { Bareilly }\end{array}$ & Total \\
\hline 1. & Farming & $78(78.00)$ & $76(76.00)$ & $81(81.00)$ & $235(78.34)$ \\
\hline 2. & Farming and Business & $12(12.00)$ & $12(12.00)$ & $9(9.00)$ & $33(11.00)$ \\
\hline 3. & Farming and Service & $10(10.00)$ & $12(12.00)$ & $10(10.00)$ & $32(10.66)$ \\
\hline & Total & $\mathbf{1 0 0}$ & $\mathbf{1 0 0}$ & $\mathbf{1 0 0}$ & $\mathbf{3 0 0}$ \\
\hline
\end{tabular}


Table.5 Distribution of farm power and improved Agricultural implements of the beneficiaries

\begin{tabular}{|c|c|c|c|c|c|}
\hline \multirow{2}{*}{$\begin{array}{l}\text { S. } \\
\text { No. }\end{array}$} & \multirow[t]{2}{*}{ Farm power } & \multicolumn{4}{|c|}{ Number of Beneficiaries } \\
\hline & & KVK Hardoi & $\begin{array}{c}\text { KVK } \\
\text { Shahjahanpur }\end{array}$ & $\begin{array}{c}\text { KVK } \\
\text { Bareilly }\end{array}$ & Total \\
\hline 1. & Tractor & 22 & 30 & 21 & 73 \\
\hline 2. & Thresher & 18 & 26 & 21 & 65 \\
\hline 3. & Bullock 1 Pair & 22 & 24 & 15 & 61 \\
\hline 4. & Tube-well & 28 & 30 & 34 & 92 \\
\hline 5. & Cultivator & 24 & 34 & 24 & 82 \\
\hline 6. & Harrow & 9 & 17 & 19 & 45 \\
\hline
\end{tabular}

Table.6 Showing association between socio-economic status and communication behavior of the beneficiaries

\begin{tabular}{|c|c|c|c|c|c|}
\hline \multirow{2}{*}{ S. No. } & \multirow{2}{*}{$\begin{array}{l}\text { Socio economics status of } \\
\text { the beneficiaries }\end{array}$} & \multicolumn{3}{|c|}{ Communication behavior score } & \multirow[t]{2}{*}{ X2 Value } \\
\hline & & Low & Medium & High & \\
\hline 1. & Low Score (up to 17) & $26(8.66)$ & $14(4.66)$ & $15(5.0)$ & \multirow{3}{*}{$12.38^{*}$} \\
\hline 2. & Medium (18-34) & $43(14.33)$ & $57(19.0)$ & $67(22.33)$ & \\
\hline 3. & High (above 35) & $27(9.0)$ & $39(13.0)$ & $12(4.0)$ & \\
\hline
\end{tabular}

* Denotes five percent significance level

Farm power and improved agricultural implements

Farm power and improved agricultural implements are also important aspect to know the personal status of the respondents.

It is apparent from the table 5 that 61 beneficiaries have one pair of bullock. 65 beneficiaries have thresher whereas 92 beneficiaries having tube-well for irrigation. 73 beneficiaries having tractor, 45 harrows while 82 beneficiaries having cultivator for ploughing. Thus, it can be concluded that majority of beneficiaries were adopting canal irrigation system followed by cultivators users. Similar findings were also given by Borude et al., (1987).

\section{Socio-economic status}

It was measured with the help of socioeconomic status scale developed by Trivedi, G.and Pareek, U. (1964). Beneficiaries were categorized in three categories viz. high, medium and low. The distribution of farmers in the three categories is presented in the graph 2.It is apparent from the graph 2 that 51.66 percent beneficiaries were from medium socio-economic status group while 26 percent beneficiaries were from high socio-economic status group. 22.34 percent beneficiaries were from lower socioeconomic status group. Thus, it can be concluded that majority of beneficiaries were from medium socio-economic status background. Ramesh Chand et al., (1997) also reported that the socio-economic factor affects the knowledge about rice production technology positive relationships

\section{Communication behavior}

The beneficiaries of the Krishi Vigyan Kendra were asked to indicate the sources by which they update themselves with the current developments/ news regarding Agriculture and other related subjects. It is 
evident from the graph 3 that group meeting/ discussion with score 5.42 followed by folder/leaflet/pamphlets (4.42), demonstration (3.66), farm magazine (2.83) and agricultural scientists (2.53) got the rank order I, II, III, IV and $\mathrm{V}$ respectively. Further input dealer (2.19), television / radio (2.13), news paper (1.77), block officials (1.11) and farmer's fair (0.19) got the rank order VI, VII, VIII, IX and $\mathrm{X}$, respectively. So it may be concluded that among all the informal sources, group meeting/discussion, folder/leaflet/pamphlets and demonstration were seems to be the most important sources of information which are most frequently used by the farmers. It can be said that television/radio was the most frequently used important information source among all those mass media sources which were used in rural area by most of the farmers.

\section{Association between socio-economic status and communication behavior of the beneficiaries}

In table 6, it has been attempt to present the data so far to project the association between personal socio-economic status and communication characteristics of the respondents.

From the table 6 it was found that there is a positive and significant association between socio-economic status and communication characteristics of the beneficiaries. The logical explanation may be attributed to the fact that they use genuine and more reliable sources of information for collecting new knowledge. They also make use of their status in this regard. Nice socio-economic background acts as a supplementary factor to influence state of seeking information.

In conclusion on the basis of above finding and observations, it may be concluding that most of the farmers were having either marginal or small holdings. Majority of the respondent were having farming as their main occupation. Beneficiaries differ significantly in case of knowledge, attitude and skill. It is due to the exposure with Krishi Vigyan Kendra of the beneficiaries. New agricultural technologies which are suitable to farmers were accepted by the farmers through Krishi Vigyan Kendra. Highest adoption at KVKs was found by the KVK Shahjahanpur, may be due to better and adequate infrastructure and other facilities. Among three selected KVKs, the KVK of the Shahjahanpur was providing best results. Nearly 50 percent beneficiaries admitted that after receiving training from $\mathrm{KVK}$, their productivity also increased. 50 percent beneficiaries fully adopted recommendations of the $\mathrm{KVK}$ while 36 percent adopted it partially.

\section{References}

Ahmad, N., Singh, S.P. and Parihar, P. (2012). "Farmers' assessment of KVK training programme." Indian Research Journal of Extension Education Special Issue (I), 186-188.

Anonymous (1995). Proceedings of state level workshop on KVKs of Uttar Pradesh, ICAR, New Delhi. Arene, C. J. (1994). Factor utilization and wage employment in agriculture. Indian Journal of labour economics, 37(2): 237-242.

Borude, S.G.; Thakare, G.G. and Dalvi, H.M.I. (1987). Socio economic bench mark survey in the command area of surya irrigation project Distt. Thane, $262 \mathrm{pp}$.

Pareek, U. and Trivedi, G. (1964). Manual of the socioeconomic status Scale (Rural), Manasayan, Delhi.

Ramesh, C., Malik, R.S., Punia, R.K. and Chand, R. (1997). Farmer's knowledge regarding rice production technology in Haryana. Haryana Journal of Research. 27(3-4): 153-154. 
Sharma, N, Arora, R.K. and Kher, S. (2013). "Attitude of farmers towards KVK training programmes and their impact." Agriculture Update, 8(1\&2), 31-34.

Singh, S. (1990). A critical analysis of T and $\mathrm{V}$ system in Bihar. Ph. D. Thesis, submitted in Department of Extension Education, R.A.U. Bihar.
Vinaya Kumar, H. M., Biradar, G. S., Nagaraj, and Govinda Gowda. V. (2013). Impact of Community Based Tank Management Project on SocioEconomic Status of Beneficiary Farmers. Environment and Ecology. 31 (2A): 620-625.

\section{How to cite this article:}

Anant Kumar and Verma, S. K. 2020. KVK's Impacts on Skill of the Respondents. Int.J.Curr.Microbiol.App.Sci. 9(09): 2975-2981. doi: https://doi.org/10.20546/ijcmas.2020.909.366 